\title{
ISOLATION AND IDENTIFICATION OF PHYTOPATHOGENIC FUNGI FROM INFECTED PLANT PARTS
}

\author{
R. THILAGAM, G. KALAIVANI, N. HEMALATHA*
}

Applied Microbiology Laboratory, Department of Microbiology, Periyar University, Salem 636011, Tamilnadu Email: aarthihema2004@yahoo.com

Received: 23 Oct 2017, Revised and Accepted: 12 Dec 2017

\section{ABSTRACT}

Objective: The present study deals with the isolation and identification of phytopathogenic fungi. The fungal isolates were Alternaria spp (Tomato early blight), Fusarium oxysporum (Fusarium wilt), Fusarium solani (daming off and root rot), Aspergillus flavus (Ear rot) and Collectotricumspp (Anthracnose).

Methods: They were isolated from infected plant parts and were identified on the basis of colony morphology and Lactophenol cotton blue (LPCB) stains were used to identify microscopic examination of spore structures. Pure cultures of the isolates were subcultured and transferred onto differential media; potato dextrose agar, malt extract agar, czapek yeast extract agar and czapek dox agar for species identification using macromorphological characteristics The morphological characteristics of these fungal elements showed various kinds of spores have been identified up to genus/species level.

Results: This study proves rapid and less expensive techniques to validate a primary alarm of contamination.

Conclusion: The five fungus which was isolated from different plant parts were very effective in distruction of the plant and found that the production was reduced due to the infection. This rapid and less expensive technique to validate a primary alarm of contamination.

Keywords: Phytofungal pathogens, Infected plant part, Microscopic examination, Fusarium, Collectotricum, Alternaria, Aspergillus

(C) 2018 The Authors. Published by Innovare Academic Sciences Pvt Ltd. This is an open access article under the CC BY license (http://creativecommons.org/licenses/by/4.0/) DOI: http://dx.doi.org/10.22159/ijcpr.2018v10i1.24404

\section{INTRODUCTION}

Plants always playing a key role in fulfilling human needs. However, as like animals, they are also prone to various infectious agents including fungal pathogens. Phytofungal pathogens pose serious problems worldwide in agriculture and food industry, especially in the subtropical and tropical regions. In addition, many also produce mycotoxins, which are harmful to humans and livestock and cause a number of diseases such as rusts, smuts, rots, downy mildew and may cause severe damage to crops. Detection of microbial pathogens refers to the process of establishing the consistent presence of a particular target organism(s) within the plant or in its environments, irrespective of the development of visible symptoms in the plant suspected to be infected by the pathogen. Diagnosis, on the other hand, relates to the identification of the nature and cause of the disease problem under investigation.

\section{Some important fungal diseases}

\section{Alternaria alternata-tomato early blight}

Tomato (Solanumlycopersicum L. "synLycopersiconesculentum Mill.") is one of the most important fruit vegetables for humans, and are cultivated. Tomato is susceptible to many diseases especially fungal diseases, the most important of which is the early blight. The disease is caused by Alternaria solani in the humid areas of the world and by Alternaria tenuis in the drier parts [1,2].

\section{Fusarium spp-damping off and root rot disease}

F. solani is the most important soilborne fungal pathogens, which develop in both cultured and non-cultured soils, causing the symptoms of damping off and root rot diseases to a wide range of vegetable and crop plants including tomato [3]. Fusarium wilt also causing the f. oxysporum. The tomato cultivars were classified into three groups of resistant, tolerant and susceptible according to their reaction to Fusarium and Rhizoctonia infection [4].

\section{Aspergillus ear rot}

Aspergillus ear rot is caused by the fungus Aspergillus flavus that may infect wounded kernels and produces green-yellow spores. This ear rot can be observed after hot, dry weather during the latter half of the growing season after pollination. Aspergillus flavus can also produce the mycotoxin called aflatoxin. Aflatoxin (AFB1) is a potently carcinogenic food contaminant produced by the filamentous fungus Aspergillus flavus, which constitutes a general food safety problem $[5,6]$.

\section{Colletotricum spp., causing chilli anthracnose}

Anthranose diease asehass has been reported to be a major constrained in chilli production in tropical, sub-tropical countries causing huge loses. The dieases is reported to affect almost all aerial parts of the plant. Chiefly, it causes fruit rot at both green and red stages primarily attacking ripe fruits, hence is also known by the name ripe fruit rot of chilli [7]. Many species of colletotricum have been associated with the pepper anthranoce in different countries. Most of the phytopathogens are transferred through soilborne.

\section{MATERIALS AND METHODS}

\section{Isolation of fungal pathogens}

Fungal pathogens are able to infect various plant parts such as roots, stems, leaves, flowers and fruits, inducing characteristic visible symptoms like spots, blights, anthracnose, wilts, rots etc. Collected infected parts of tomato, chilli, corn, and maize was cut into small pieces. After washing the tissues thoroughly in sterile water, the causal fungi are isolated from plant tissues exhibiting clear symptoms. The infected tissues along with adjacent small unaffected tissue are cut into small pieces (2-5 mm squares) and by using flame-sterilized forceps, they are transferred to sterile petridishes containing $0.1 \%$ mercuric chloride solution used for surface sterilization of plant tissues. The plant parts were transferred to PDA plates and Incubated for 5-7 d for the complete growth of fungi. The resulted fungi were purified using the hyphal tips technique on Rose Bengal medium and then subculture of each isolated fungus on slant medium for future studies. The fungi were identified according to cultural characters described by Gilman (1957), Barnett and Hunter (1972) and Nelson et al. (1982) [8-10].

The fungal pathogens from stems, roots, or fruits in which they may be present in the deep-seated tissue have to be isolated by culturing 
pieces of internal tissues. The infected tissues are thoroughly washed in sterile water and then swabbed with cotton wool dipped into $80 \%$ ethanol, followed by exposure to an alcohol flame for a few seconds. The outer layer of tissues are quickly removed by a flame sterilized scalpel. Small pieces from the central core of tissues in the area of the advancing margin of infections are removed by a sterilized scalpel or scissors and sterilized by dipped into $90 \%$ alcohol then flaming for a few seconds. The tissues thus sterilizes, are transferred to PDA plates and incubated for 5-7 d.

\section{Identification of fungal pathogens}

Rhizosphere microflora were identified based on colony and morphological characters [11]. The isolated fungi were identified to the genus level and species which was possible on the basis of micro morphological and macro-morphological characteristics using suitable media, slide cultures and the most updated keys for identifications with sporulation. Pure cultures of the isolates were subcultured and transferred onto differential media; potato dextrose agar, malt extract agar, czapek yeast extract agar and czapek dox agar for species identification using macromorphological characteristics All the plates were grown in triplicates for the complete isolation and purification of plant pathogenic fungi the microscopic photo plates were tabulated.

\section{RESULTS}

The results of the present investigation revealed with work done which was recorded in the table 1. These include Alternaria, Fusarium solani, Fusarium oxysporum, Aspergillus flavus, and colletotricum spp. pure cultures of the isolated fungi were identified according to the cultural properties, morphological, and microscopical characteristics of each fungus $[16,17]$. Morphological characteristics as a primary tool for fungi identification should be embraced and more personnel with the knowledge are required since modern and faster techniques are expensive. This study has provided useful information about the toxigenic fungi associated with plant parts which may affect the human health, agricultural production and also economic loss.

Table 1: Isolated pathogen with respective host

\begin{tabular}{cll}
\hline S. No. & Name of fungi & Host plant \\
\hline 1. & Alternaria alternate. & Solanumlycopersicum \\
2. & Fusarium oxysporum & Solanumlycopersicum \\
3. & Fusarium solani & Solanumlycopersicum \\
4. & Aspergillus flavus & Zea mays \\
5. & Colletotricum spp., & Capsicum annum L. \\
\hline
\end{tabular}
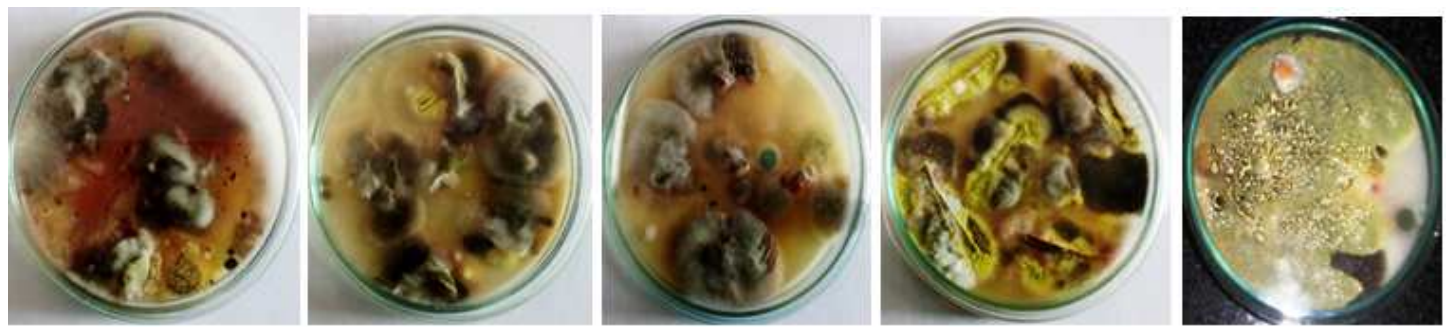

1. Isolation of pathogenic fungi from plant parts

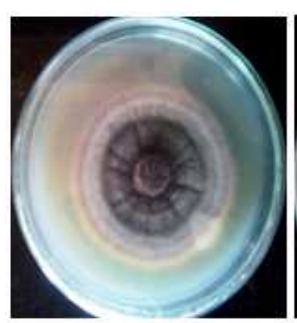

a

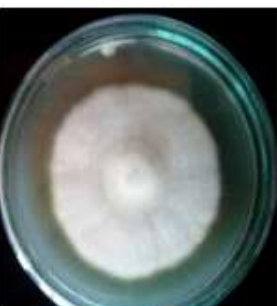

b

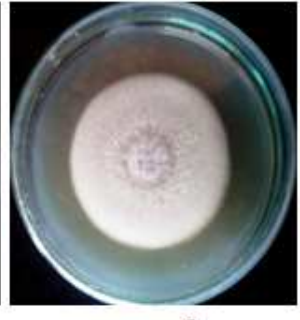

c

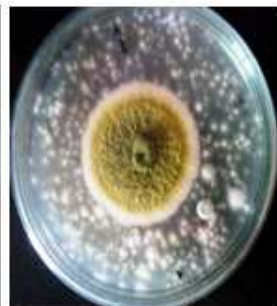

d

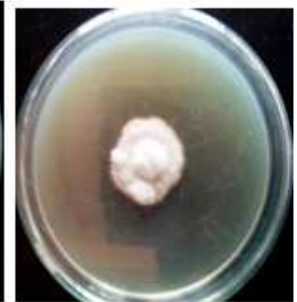

e

2. Pure cultures of isolated fungi on PDA plates
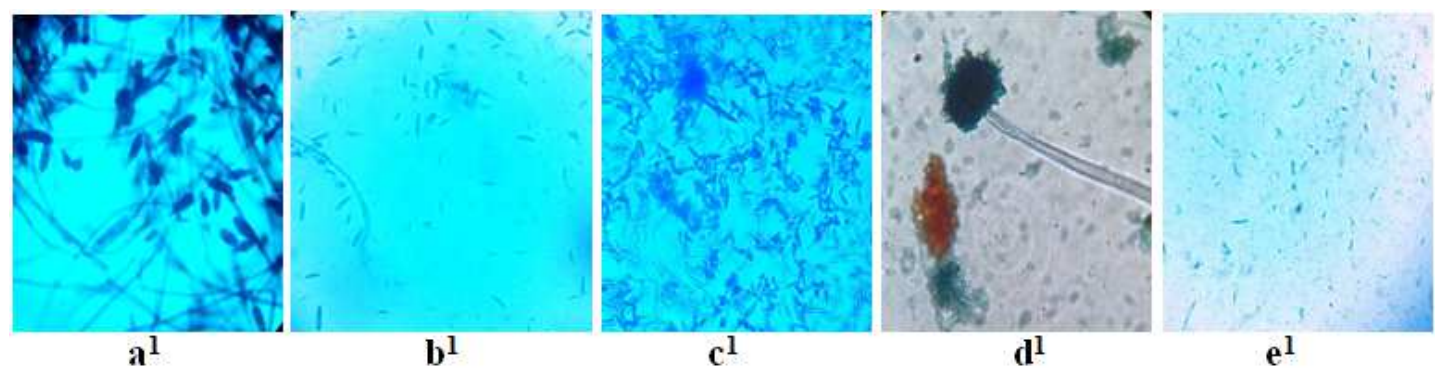

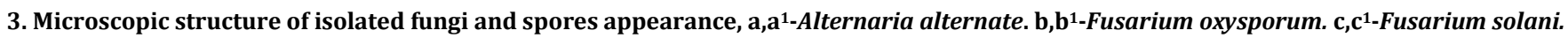
d,d'-Aspergillus flavus. e,e1-Colletotricum spp 


\section{DISCUSSION}

Determination of infectious routes of plant pathogens and their mechanisms of infection are of great importance in any disease control program (18). Our finding coincides with the work of Elisaneet al., (2008), who also isolated four strains from the contaminated soil [12]. They were identified as Aspergillus sp. Kostadinovaaet al. (2014) isolated Aspergillus and Penicillium from Antarctica [13]. Sharma (2010) [14] isolated some fungi at Darjeeling tea garden soil and Sharma et al. (2011) reported some fungi from Lachung soil [15]. The result was compared with the study of other workers for for the fungal strains Alternaria alternate, Fusarium oxysporum, Fusarium solani, Aspergillus flavus, and colletotricum spp.,

\section{CONCLUSION}

The five fungus which was isolated from different plant parts were very effective in distruction of the plant and found that the producion were reduced due to the infection. This rapid and less expensive technique to validate a primary alarm of contamination.

\section{ACKNOWLEDGEMENT}

The authors thank the Department of Microbiology, Periyar University for providing all the lab facilities for this study.

\section{AUTHORS CONTRIBUTIONS}

All the author have contributed equally

\section{CONFLICT OF INTERESTS}

Declared none

\section{REFERENCES}

1. Kapoor JN, Hingorani MK. Alternaria leaf spot and fruit rot of Brinjal. Indian J Agric Sci 1958;28:109-14.

2. Tandon RN, Chalurvedi C. Alternaria leaf spot of tomato. Proc Natl Academy Sci India 1965;35:286-90.

3. Abu Taleb, Amira M, Kadriya El-Deeb, Fatimah 0, Al-Otibi. Assessment of antifungal activity of rumexvesicarius L. and ziziphusspina-christi (L.) wild extracts against two phytopathogenic fungi. Afr J Microbiol Res 2011;5:1001-11.

4. Moustafa SES, Khafagi YS. The reaction of certain tomato cultivars to fusarium wilt and root rot diseases caused by fusarium oxysporium f. sp. lycopersici and rhizoctoniasolani, respectively. Assiut J Agric Sci 1992;23:199-207.

5. Ellis WO, Smith JP, Simpson BK, Oldham JH. Aflatoxins in food: occurrence, biosynthesis, effects on organisms, detection, and methods of control. Crit Rev Food Sci Nutr 1991;30:403-39.

6. Calvo AM, Wilson RA, Bok JW, Keller NP. The relationship between secondary metabolism and fungal development. Microbiol Mol Biol Rev 2002;66:447-59.

7. Agrios GN. Plant pathology. St. Louis, MO: Academic Press; 2005.

8. Gilman CJ. A Manual of Soil Fungi. Iowa State College Press: USA; 1957. p. 450.

9. Barnett HL, Hunter BB. Illustrated Genera of Imperfect Fungi. Burgess. Pub. Co., Minnesota, USA; 1972. p. 241.

10. Nelson PE, Toussoun TA, Marasas WFO. Fusarium spp. An Illustrated Manual of Identification. The Pennesylvania Univ. Press; Univ, Park: 1982. p. 216.

11. Venkateswarlu N, Sireesha O, Aishwayra S, Vijaya T, Sriramulu A. Isolation, screening of rhizosphere fungi antagonistic to rice stem rot disease pathogen sclerotium orizae catt. Asian J Pharm Clin Res 2015;18:54-7.

12. Elisane OdS, Célia FCdR, Cátia TdP, Ana VLS, Janaína FdMB, Susana JK, et al. Pre-screening of filamentous fungi isolated from a contaminated site in Southern Brazil for bioaugmentation purposes. Afr J Biotechnol 2008;7:1314-7.

13. Kostadinova N, Vassilev S, Spasova B, Angelova M. Cold stress in antarctic fungi targets enzymes of the glycolytic pathway and tricarboxylic acid cycle biotechnol. Biotechnology 2011;25:50-7.

14. Sharma K. Soil mycoflora of darjeeling tea garden. Bioinfolet 2010;7:142-3.

15. Sharma KR, Luka, S Deo. Fungal spora in soil of Lachung. Kavaka 2011;37:67-8.

16. Ara I, Bukhari NA, Perveen K, Bakir MA. Antifungal activity of some actinomycetes isolated from Riyadh soil, Saudi Arabia: an evaluation for their ability to control Alternaria caused tomato blight in greenhouse pot trial. Afr J Agric Res 2012;7:2042-50.

17. Loliam B, Morinaga $T$, Chaiyanan S. Biocontrol of phytophthorainfestans fungal pathogen of seedling damping off disease in an economic plant nursery. Hindawi Publ Corp Psychem 2012;12:1-6.

18. Twumasi P, Ohene-Mensah G, Moses E. The rot fungus Botryodiplodiatheobromae strains cross infect cocoa, mango, banana and yam with significant tissue damage and economic losses. Afr J Agric Res 2014;9:613-9. 